\title{
New Approach for Cardiovascular Diseases (CVD) Treatment ${ }^{\dagger}$
}

\author{
Adriana Cambón *, Lilia Arellano, Eva Villar-Álvarez, Xaniar Smailzadeh, Silvia Barbosa Fernández and \\ Pablo Taboada Antelo
}

Citation: Cambón, A.; Arellano, L.; Villar-Álvarez, E.; Smailzadeh , X.; Barbosa, S.; Taboada, P. New Approach for Cardiovascular Diseases (CVD) Treatment. Mater. Proc. 2021, 4, 19. https://doi.org/10.3390/ IOCN2020-07993

Academic Editors: Ana María Díez-Pascual, Antonio Di Bartolomeo and Guanying Chen

Published: 12 November 2020

Publisher's Note: MDPI stays neutral with regard to jurisdictional claims in published maps and institutional affiliations.

Copyright: $\odot 2021$ by the authors. Licensee MDPI, Basel, Switzerland. This article is an open access article distributed under the terms and conditions of the Creative Commons Attribution (CC BY) license (http://creativecommons.org/licenses/by/4.0/).
Facultad de Física, University of Santiago de Compostela, Santiago de Compostela, 15705 Galicia, Spain; liliaguadalupe.arellano@rai.usc.es (L.A.); eva.mailbox1@gmail.com (E.V.- Á);

xaniar.esmailzadeh@usc.es (X.S.); silvia.barbosa@usc.es (S.B.F.); pablo.taboada@usc.es (P.T.A.)

* Correspondence: adrianacambonfreire@gmail.com

† Presented at the 2nd International Online-Conference on Nanomaterials, 15-30 November 2020; Available online: https://iocn2020.sciforum.net/.

Abstract: Cardiovascular disease (CVD) is a general term that includes diseases that affect the circulatory system and/or the heart. Their underlying pathology is atherosclerosis, an inflammatory disease characterized by the accumulation of lipids, inflammatory cells and fibrous tissue in the arteries' internal wall, provoking to some extent their obstruction. Atherosclerosis is still addressed as a simple disease instead of the complex interplay of different types of cells and cascade signaling pathways, so the use of any single imaging or therapeutic agent alone is unlikely to provide a satisfactory outcome. Hence, other treatment strategies need to be implemented, in particular, those using new nanomaterials able to target the plaque and to efficiently treat it, and that can be easily released by the body without provoking adverse effects. With this background, we have designed a biocompatible drug delivery vehicle that efficiently loads and protects the drug Atorvastatin (ATO reduces the LDL levels) while a folate receptor in the external shell targets inflamed areas. To avoid the common toxic effects of folic acid (FA) or ATO in the body at certain concentrations, the vehicle will provide covalent attachment for the FA on the surface and cage structure for ATO protection. To complement the treatment, genetic material will be included in a separate compartment to actively influence the regulation of immune responses and inflammatory disorders.

Keywords: Cardiovascular disease; atorvastatine; drug delivery; nanoparticles

Supplementary Materials: The following are available online at https:/www.mdpi.com/article/ 10.3390/IOCN2020-07993/s1.

Institutional Review Board Statement: Not applicable.

Informed Consent Statement: Not applicable.

Data Availability Statement: Data sharing is not applicable to this article. 